\title{
Raloxifene-stimulated experimental breast cancer with the paradoxical actions of estrogen to promote or prevent tumor growth: A unifying concept in anti-hormone resistance
}

\author{
GREGOR M. BALABURSKI ${ }^{1}$, RITA C. DARDES ${ }^{2}$, MICHAEL JOHNSON ${ }^{3}$, BASSEM HADDAD $^{3}$, \\ FANG ZHU ${ }^{1}$, ERIC A. ROSS ${ }^{1}$, SUROJEET SENGUPTA ${ }^{3}$, ANDRES KLEIN-SZANTO ${ }^{1}$, \\ HONG LIU ${ }^{4}$, EUN SOOK LEE ${ }^{4}$, HELEN KIM $^{3}$ and V. CRAIG JORDAN ${ }^{3}$ \\ ${ }^{1}$ Fox Chase Cancer Center, 333 Cottman Avenue, Philadelphia, PA 19111, USA; \\ ${ }^{2}$ Department of Gynecology, Federal University of São Paulo (UNIFESP), Rua João Cachoeria 488cj 602, \\ CEP 04535-001 São Paulo, Brasil; ${ }^{3}$ Georgetown University Medical Center, Lombardi Comprehensive Cancer Center, \\ 3970 Reservoir Road NW, Washington, D.C. 20057; ${ }^{4}$ Robert H. Lurie Comprehensive Cancer Center, \\ Feinberg School of Medicine, Northwestern University, Chicago, IL 60611, USA
}

Received March 29, 2010; Accepted May 2, 2010

DOI: 10.3892/ijo_00000687

\begin{abstract}
We have previously demonstrated that prolonged treatments with raloxifene (RAL) in vitro will result in phase II RAL resistance and RAL-induced tumor growth. Clinical interest prompted us to re-examine RAL resistance in vivo, particularly the effects of long-term treatments (a decade or more) on the evolution of RAL resistance. In this study, we have addressed the question of this being a reproducible phenomenon in wild-type estrogen receptor (ER)-positive human breast cell line MCF-7. MCF-7 cells cultured under estrogen-deprived conditions in the presence of $1 \mu \mathrm{M}$ RAL for more than a year develop RAL resistance resulting in an independent cell line, MCF7-RAL. The MCF7-RAL cells grow in response to both estradiol $\mathrm{E}_{2}$ and RAL. Fulvestrant (FUL) blocks RAL and $\mathrm{E}_{2}$-mediated growth. Transplantation of MCF7-RAL cells into athymic ovariectomized mice and treatment with physiologic doses of $\mathrm{E}_{2}$ causes early $\mathrm{E}_{2}$-stimulated tumor growth. In contrast, continuous treatment of implanted animals with daily oral RAL (1.5 mg daily) causes growth of small tumors within 15 weeks. Continuous re-transplantation of the tumors growing in RAL-treated mice indicated that RAL stimulated tumor growth. Tumors in the untreated mice did not grow. Bi-transplantation of MCF7- $\mathrm{E}_{2}$ and MCF7RAL tumors into the opposing mammary fat pads of the same ovariectomized animal demonstrated that $\mathrm{MCF} 7-\mathrm{E}_{2}$
\end{abstract}

Correspondence to: Dr V. Craig Jordan, Georgetown University Medical Center, Lombardi Comprehensive Cancer Center, 3970 Reservoir Road NW, Washington, D.C. 20057, USA

E-mail: vcj2@georgetown.edu

Key words: raloxifene, tamoxifen, osteoporosis, breast cancer grew with $\mathrm{E}_{2}$ stimulation and not with RAL. Conversely, MCF7-RAL tumors grew with RAL and not $\mathrm{E}_{2}$, a characteristic of phase II resistance. Established phase II resistance of MCF7-RAL tumors was confirmed following up to 7 years of serial transplantation in RAL-treated athymic mice. The $\mathrm{ER} \alpha$ was retained in these tumors. The cyclical nature of RAL resistance was confirmed and extended during a 2-year evolution of the resistant phases of the MCF7-RAL tumors. The MCF7-RAL tumors that initially were inhibited by $\mathrm{E}_{2}$ grew in the presence of $E_{2}$ and subsequently grew with either RAL or $E_{2}$. RAL remained the major grow stimulus and RAL enhanced $\mathrm{E}_{2}$-stimulated growth. Subsequent transplantation of $E_{2}$ stimulated tumors and evaluations of the actions of RAL, demonstrated robust $\mathrm{E}_{2}$-stimulated growth that was blocked by RAL. These are the characteristics of the antiestrogenic actions of RAL on $\mathrm{E}_{2}$-stimulated breast cancer growth with a minor component of phase I RAL resistance. Continuous transplantation of the phase I RAL-stimulated tumors for $>8$ months causes reversion to phase II resistance. These data and literature reports of the cyclical nature of anti-androgen/androgen responsiveness of prostate cancer growth, illustrate the generality of the evolution of antihormonal resistance in sex steroid-sensitive target tissues.

\section{Introduction}

Selective estrogen receptor (ER) modulators (SERMs) are compounds that bind to the ER and based on tissue specificity, act as agonists or antagonists (1). Tamoxifen (TAM), the first SERM, is a proven agent for treatment of breast cancer (2) and breast cancer chemoprevention $(3,4)$. Laboratory studies during the 1980s demonstrated that long-term tamoxifen treatment stimulated the growth of ER-positive MCF-7 breast tumors in vivo $(5,6)$. This unique form of acquired resistance to a cancer therapy raised clinical concerns 
about extending adjuvant tamoxifen therapy. However, the risk of developing endometrial cancer during the use of tamoxifen for chemoprevention of breast cancer (4) prompted the examination of other compounds that would capitalize on the gains in breast cancer prevention made with tamoxifen but with a superior safety profile.

Raloxifene (also known as keoxifene or LY156,758) (7), a second generation SERM, inhibits the growth of 7,12dimethylbenzanthracene (DMBA)-induced tumors in rats (8), prevents the development and growth of estrogen-dependent $\mathrm{N}$-nitrosomethylurea (NMU)-induced mammary carcinoma in rats (9) and maintains bone density in ovariectomized rats (10). The recognition that non-steroidal anti-estrogens like tamoxifen and raloxifene selectively exhibited estrogen-like effects in bone and anti-estrogenic effects in breast and mammary tissue $(9,10)$ suggested a new strategy to prevent breast cancer by treating post-menopausal women to prevent and treat osteoporosis and prevent breast cancer at the same time (11).

The clinical finding that patients treated with raloxifene to improve bone density (12) exhibited significant decrease in the rates of breast cancer (13), provided a clinical proof of the laboratory principle and demonstrated raloxifene's potential as a breast cancer chemopreventive agent. Data from the study of tamoxifen and raloxifene (STAR) trial (14), which directly compared raloxifene to tamoxifen for breast cancer chemoprevention, indicated that raloxifene has similar chemopreventive properties as tamoxifen but with a significantly better safety profile. A subsequent clinical trial (15) examining the effects of raloxifene on coronary heart disease (CHD) did not achieve its goals but confirmed the role of raloxifene as a breast cancer chemoprevention agent with no increase in endometrial cancer. The evaluation by Martino and coworkers (16) that long-term raloxifene treatment for the prevention of osteoporosis does not increase endometrial cancer but maintains an inhibiting effect on breast cancer incidence suggests that the clinical community may use raloxifene for indefinite periods. However, the discovery that acquired tamoxifen resistance evolves $(17,18)$ raises new questions about acquired resistance to raloxifene treatments.

Acquired tamoxifen resistance is sub-divided into 3 phases: i) phase I, in which estrogen and the SERM stimulate tumor growth, ii) phase II, in which the SERM stimulates tumor growth and estrogen induces tumor regression; iii) phase III resistance or autonomous growth (1). Laboratory studies indicate that long-term SERM treatments result in hypersensitivity to low, physiological doses of estrogen resulting in breast tumor regression and possibly estrogen-induced apoptosis. It is important to note that these observations were initially made with an estrogen-supersensitive clone of MCF-7 breast cancer cells (WS8) using only tamoxifen treatment for $5-10$ years in vivo $(17,18)$ and raloxifene-resistant model $(19,20)$ in vitro and few weeks $(20)$ or a year or two $(19,20)$ in vivo. These data are not confined to SERM-resistant models as similar observations were made in long-term estrogendeprived breast cancer cells (21-24). The findings that physiological estrogen causes dramatic tumor repression in anti-hormone-resistant breast cancer $(17,18)$ are reminiscent of the early clinical trials utilizing high doses of diethylstilbestrol
(DES) $(25,26)$ to treat breast cancer in post-menopausal patients many years after their menopause. Moreover, recent clinical trial $(27,28)$ evaluating the role of estrogen treatments in women with advanced breast cancer following acquired resistance to anti-hormone therapy noted a $31 \%$ objective response and indicated a substantial role for high dose estrogen treatments in hormone-dependent breast cancer resistant to conventional endocrine therapies.

The current 10-year laboratory study has paralleled the translation of the new biology of apoptotic action $(17,18,21,23)$ to clinical trials $(27,28)$. Most importantly, the increasing clinical use of raloxifene for the prevention of osteoporosis in post-menopausal women implies that breast cancer that develops during a decade or more of raloxifene treatment will have developed raloxifene resistance. It is important to address this emerging clinical problem.

Our goal was to revisit this question by utilizing wildtype MCF-7 cells to recreate a raloxifene-resistant variant of MCF7 cells in vitro. The failure of wild-type MCF-7 cells to create acquired resistance in vivo would expose an inadequacy of laboratory models or imply that acquired raloxifene resistance would not occur in the clinic. This was not the case as the answer is yes to the first question and the answer to the second question requires clinical investigation. We subsequently used the new model in vivo to evaluate the actions of physiological estrogen and raloxifene on the growth responses of raloxifene-stimulated tumors passaged over a decade in ovariectomized athymic mice. This laboratory strategy mimics the clinical duration of raloxifene exposure.

\section{Materials and methods}

Cell lines and tissue culture. The MCF7 breast cells were a generous gift of Dr Myles Brown (Harvard) in 1995. The MCF7 cells were maintained in a DMEM red medium (Invitrogen, Carlsbad, CA) supplemented with $10 \%$ fetal bovine serum (FBS), $2 \mathrm{mM}$ glutamine, $100 \mathrm{U} / \mathrm{ml}$ penicillin, $100 \mu \mathrm{g} / \mathrm{ml}$ streptomycin and $10 \mathrm{mM}$ non-essential amino acids (NEAA). Raloxifene-resistant MCF7 cells (MCF7RAL) were derived by continuously culturing the MCF7 cells for up to 10 years in estrogen-free media: DMEM yellow media with $10 \%$ charcoal-stripped FBS, 2 mM glutamine, $100 \mathrm{U} / \mathrm{ml}$ penicillin, $100 \mu \mathrm{g} / \mathrm{ml}$ streptomycin and $10 \mathrm{mM}$ NEAA, supplemented with $1 \mu \mathrm{M}$ raloxifene- $\mathrm{HCl}$. All cell lines were cultured at $37^{\circ} \mathrm{C}, 5 \% \mathrm{CO}_{2}$ and $95 \%$ humidity.

Verification of cell line identity by DNA fingerprinting. The identity of the cell lines was verified by DNA fingerprinting using the commercially available kit, PowerPlex ${ }^{\circledR} 1.2$ System (Promega). This system allows the co-amplification and twocolor detection of nine loci (eight STR loci and the Y-specific Amelogenin) and provides a powerful level of discrimination in excess of 1 in $10^{8}$ (29). The following STR markers were tested: CSF1PO, TPOX, TH01, vWA, D16S539, D7S820, D13S317 and D5S818. The cells were harvested by trypsinization and DNA was isolated from the resultant cell pellets using standard methods (30). The PCR amplification was performed according to the manufacturer's recommended protocol. Fragment analysis of the PCR product was achieved using an ABI 3100 capillary sequencer (Applied Biosystems, 
Foster City, CA). The GeneMapper ${ }^{\circledR}$ software (Applied Biosystems) was used to score the fragment sizes and generate an alphanumeric score for each locus. The data generated were then compared to allelic alphanumeric scores for MCF-7 and ECC-1 reported in the ATCC STR database generated using the same assay (ATCC, VA).

DNA growth assay. MCF7 and MCF7-RAL cells were seeded in estrogen-free media 4 days prior to start of the experiment. After 3 days of ligand starvation the appropriate numbers of cells were seeded in a 24-well plate. Twenty-four hours later, which was denoted as day 0 , the cells were appropriately treated. The media containing treatments were changed every other day. All drugs were solubilized in ethanol and were added as 1:1000 dilutions. Following 15 days of treatment the DNA content of the cells was measured as previously described (31) with VersaFluor fluorometer (Bio-Rad Laboratories, Hercules, CA).

\section{Animal procedures}

MCF7 tumor models. The MCF7- $\mathrm{E}_{2}$ breast tumor model was developed by bilaterally injecting $1 \times 10^{7} \mathrm{MCF} 7$ cells into the mammary fat pads of ovariectomized athymic CrTac: NCRFoxn $1<$ nu $>$ mice (Taconic, Hudson, NY) (32), 4-6 weeks of age, implanted with silastic $17 ß$-estradiol capsules. The raloxifene-resistant MCF7-RAL model was similarly developed by injecting $1 \times 10^{7}$ raloxifene-resistant MCF7-RAL cells into the mammary fat pads of ovariectomized female mice. RAL treatments were started $24 \mathrm{~h}$ post-implantation by administering $1.5 \mathrm{mg}$ RAL or $.005 \mathrm{mg}$ TAM via oral gavage. The MCF7-RAL tumor xenograft model was maintained by excising the established MCF7-RAL tumors, removing all extraneous tissues and dissecting them into approximately $1-2 \mathrm{~mm}^{3}$ pieces that were then implanted by trochar into the mammary fat pads of naïve mice subsequently treated with RAL. The RAL-resistant MCF7-RAL model was continuously passaged into RAL-treated athymic mice over a 10 -year period. Established tumors were measured every week or as needed with Vernier calipers and cross sectional area of the tumor was calculated utilizing the formula: Length (1) $\mathrm{x}$ width (w) $\mathrm{x} \pi / 4$.

Drug administration. The raloxifene solution for oral gavage was prepared by grinding 10 commercially available Evista $^{\circledR}$ tablets and dissolving them into $10 \%$ PEG 400/ Tween-80 (Sigma, St. Louis, MO) solution to a final concentration of $15 \mathrm{mg} / \mathrm{ml}$. Silastic $17 ß$-estradiol capsules were manufactured as previously described (33) and were subcutaneously implanted in the mice dorsal region. The $0.3-\mathrm{cm}$ capsule delivered the equivalent of menopausal levels of estrogen while the $1.0-\mathrm{cm}$ capsule delivered the equivalent of pre-menopausal levels of estrogen (34). Fulvestrant (Fasoldex/ICI 182,780, AstraZeneca) is commercially available and was purchased from the hospital pharmacy. Total fulvestrant (FUL) (10 mg) was injected bi-weekly, subcutaneously (35). All animal studies were approved by the Fox Chase institutional animal care and use committee.

$R N A$ extractions, reverse transcriptase reactions and realtime qPCR. Total RNA was extracted with TRIzol reagent (Invitrogen) and further purified using RNeasy Mini and
Midi kits (Qiagen, Valencia, CA). Total RNA (1 $\mu \mathrm{g})$ was reversely transcribed with the High Capacity cDNA reverse transcriptase kit (Applied Biosystems) following manufacturer's instructions. The sequences of the primers utilized for real-time qPCR are as follows: tffl forward primer, 5'-CATC GACGTCCCTCCAGAAGAG-3'; tffl reverse primer, 5'-CTC TGGGACTAATCACCGTGCTG-3'; $36 B 4$ forward primer, 5'-GTGTTCGACAATGGCAGGCAT-3'; 36 B4 reverse primer, 5'-GACACCCTCCAGGAAGCGA-3'; c-myc forward primer, 5'-GCCACGTCTCCACACATCAG-3'; c-myc reverse primer, 5'-TCTTGGCAGCAGGAATAGTCCTT-3'; ebag9 forward primer, 5'-CTGGCAGAGGACGGAAATTA-3'; ebag9 reverse primer, 5'-TCATCCCAGGAAGTCCACTC-3'; the primer sets for egfr and her2 were previously described (36,37). Real-time qPCR was performed using the 7900HT real-time PCR system (Applied Biosystems), the amplicons were detected with SYBR-Green and analysis was performed utilizing the $2^{-\Delta \Delta t}$ method (38).

Transient transfections and luciferase assays. MCF7 and MCF7-RAL cells were maintained in estrogen-free medium for 3 days and seeded at confluency of 150,000 cells per 6 -well plate. The cells were co-transfected with $5 \operatorname{ERE}(5 \mathrm{X})$ TA ffluc and pTA-srluc utilizing TransIT LT1 transfection agent (Mirus, Madison, WI) (39). Luciferase activity was measured utilizing the Dual-luciferase reporter assay system (Promega) with Mithras LB 940 (Berhold Technologies, Bad Wildbad, Germany) microplate reader.

Protein isolation and Western blot. The MCF7 and MCF7RAL cells were cultured in estrogen-free media for 3 days and seeded at $50-60 \%$ confluency. Twenty-four hours postseeding the cells were treated with the appropriate drug or drug combination. Following 24-h treatment, the cells were washed with PBS and scraped off the plates. After brief centrifugation at $4^{\circ} \mathrm{C}$ the PBS was aspirated and the cells were resuspended in RIPA buffer (Sigma) supplemented with complete mini protease inhibitor cocktail tablets (Roche Diagnostics, Indianapolis, IN), phosphatase inhibitor cocktail set (EMD Biosciences, La Jolla, CA) and benzonase (Call Biochem, La Jolla, CA). The cells were then incubated for additional $30 \mathrm{~min}$ at $4^{\circ} \mathrm{C}$ with rotation. The debris was removed with centrifugation at $12000 \mathrm{rpm}$ for $30 \mathrm{~min}$ at $4^{\circ} \mathrm{C}$.

Tumor protein lysates were generated by pulverizing flash-frozen tumors to a fine powder with a Bio-pulverizer (BioSpec Products Inc., Bartlesville, OK) and resuspending them in $400 \mu 1$ of RIPA buffer supplemented with complete mini protease inhibitor cocktail tablets and phosphatase inhibitors cocktail set. The suspension was than sonicated 3 times at maximum power and centrifuged at $12000 \mathrm{rpm}$ for $20 \mathrm{~min}$ at $4^{\circ} \mathrm{C}$. Supernatants were collected and stored at $-80^{\circ} \mathrm{C}$.

Protein quantitation was performed with the Bicinchoninic acid (BCA) Protein Assay (Pierce, Rockford, IL) as per the manufacturer's protocol. Readings were obtained with a microplate reader (SpectraMax Plus, Molecular Devices, Sunnyvale, CA). Protein $(50 \mu \mathrm{g})$ was resolved by SDSPAGE and Western blotting was performed as previously described (40). Antibodies used were as follows: ER $\alpha$ G-20 (Santa Cruz Biotechnology, Inc., Santa Cruz, CA), phospho 
A.

\begin{tabular}{|c|c|c|c|c|c|c|c|c|c|c|c|c|c|c|c|c|c|c|}
\hline \multirow[b]{2}{*}{ cell line: } & \multicolumn{2}{|c|}{ D5S818 } & \multicolumn{2}{|c|}{ D13S317 } & \multicolumn{2}{|c|}{ D7S820 } & \multicolumn{2}{|c|}{ D16S539 } & \multicolumn{2}{|c|}{ vWA } & \multicolumn{2}{|c|}{ TH01 } & \multicolumn{2}{|c|}{ Amelogenin } & \multicolumn{2}{|c|}{ TPOX } & \multicolumn{2}{|c|}{ CSF1PO } \\
\hline & $\begin{array}{c}\text { allele } \\
1\end{array}$ & $\begin{array}{c}\text { allele } \\
2\end{array}$ & $\begin{array}{c}\text { allele } \\
1\end{array}$ & $\begin{array}{c}\text { allele } \\
2\end{array}$ & $\begin{array}{c}\text { allele } \\
1\end{array}$ & $\begin{array}{c}\text { allele } \\
2\end{array}$ & $\begin{array}{c}\text { allele } \\
1\end{array}$ & $\begin{array}{c}\text { allele } \\
2\end{array}$ & $\begin{array}{c}\text { allele } \\
1\end{array}$ & $\begin{array}{c}\text { allele } \\
2\end{array}$ & $\begin{array}{c}\text { allele } \\
1\end{array}$ & $\begin{array}{c}\text { allele } \\
2\end{array}$ & $\begin{array}{c}\text { allele } \\
1\end{array}$ & $\begin{array}{c}\text { allele } \\
2\end{array}$ & $\begin{array}{l}\text { allel } \\
\text { e } 1\end{array}$ & $\begin{array}{c}\text { allele } \\
2\end{array}$ & $\begin{array}{c}\text { allele } \\
1\end{array}$ & $\begin{array}{c}\text { allele } \\
2\end{array}$ \\
\hline $\begin{array}{l}\text { MCF-7 } \\
\text { ATCC }\end{array}$ & 11 & 12 & 11 & 11 & 8 & 9 & 11 & 12 & 14 & 15 & 6 & 6 & $x$ & $x$ & 9 & 12 & 10 & 10 \\
\hline $\begin{array}{c}\text { MCF7-WS8 } \\
\text { p24 }\end{array}$ & & 12 & 11 & 11 & 8 & 9 & 11 & 12 & & 15 & 6 & 6 & $x$ & $x$ & 9 & 12 & 10 & 10 \\
\hline $\begin{array}{c}\text { MCF7/5C } \\
\text { p217 }\end{array}$ & & 12 & 11 & 11 & 8 & 9 & 11 & 12 & 14 & 15 & 6 & 6 & $x$ & $x$ & 9 & 12 & 10 & 11 \\
\hline $\begin{array}{c}\text { MCF7/2A } \\
\text { p549 }\end{array}$ & & 12 & 11 & 11 & 8 & 9 & 11 & 12 & 14 & 15 & 6 & 6 & $x$ & $x$ & 9 & 12 & 10 & 10 \\
\hline $\begin{array}{l}\text { MCF7/ICI } \\
\text { p42 }\end{array}$ & & 12 & 11 & 11 & 8 & 9 & 11 & 12 & & 15 & 6 & 6 & $x$ & $x$ & 9 & 12 & 10 & 10 \\
\hline $\begin{array}{c}\text { MCF7/RAL } \\
\text { p83 }\end{array}$ & 12 & 13 & 11 & 11 & 8 & 9 & 11 & 12 & 14 & 15 & 6 & 6 & $x$ & $\mathrm{x}$ & 9 & 12 & 10 & 10 \\
\hline
\end{tabular}

B.

\begin{tabular}{|c|c|c|c|c|c|c|c|c|c|c|c|c|c|c|c|c|c|c|}
\hline \multirow[b]{2}{*}{ cell line } & \multicolumn{2}{|c|}{ D5S818 } & \multicolumn{2}{|c|}{ D13S317 } & \multicolumn{2}{|c|}{ D7S820 } & \multicolumn{2}{|c|}{ D16S539 } & \multicolumn{2}{|c|}{ vWA } & \multicolumn{2}{|c|}{ TH01 } & \multicolumn{2}{|c|}{ Amelogenin } & \multicolumn{2}{|c|}{ TPOX } & \multicolumn{2}{|c|}{ CSF1PO } \\
\hline & $\begin{array}{c}\text { allele } \\
1\end{array}$ & $\begin{array}{c}\text { allele } \\
2\end{array}$ & $\begin{array}{c}\text { allele } \\
1\end{array}$ & $\begin{array}{c}\text { allele } \\
2\end{array}$ & $\begin{array}{c}\text { allele } \\
1\end{array}$ & $\begin{array}{l}\text { allele } \\
2\end{array}$ & $\begin{array}{c}\text { allele } \\
1\end{array}$ & $\begin{array}{c}\text { allele } \\
2\end{array}$ & $\begin{array}{c}\text { allele } \\
1\end{array}$ & $\begin{array}{c}\text { allele } \\
2\end{array}$ & $\begin{array}{c}\text { allele } \\
1\end{array}$ & $\begin{array}{l}\text { allele } \\
2\end{array}$ & $\begin{array}{c}\text { allele } \\
1\end{array}$ & $\begin{array}{c}\text { allele } \\
2\end{array}$ & $\begin{array}{c}\text { allele } \\
1\end{array}$ & $\begin{array}{c}\text { allele } \\
2\end{array}$ & $\begin{array}{c}\text { allele } \\
1\end{array}$ & $\begin{array}{c}\text { allele } \\
2\end{array}$ \\
\hline MCF-7 ATCC & 11 & 12 & 11 & 11 & 8 & 9 & 11 & 12 & 14 & 15 & 6 & 6 & $\mathrm{x}$ & $\mathrm{x}$ & 9 & 12 & 10 & 10 \\
\hline $\begin{array}{l}\text { MCF7 (GMB) } \\
\text { p184 }\end{array}$ & 11 & 12 & 11 & 11 & 8 & 9 & 11 & 12 & 14 & 15 & 6 & 6 & $x$ & $x$ & 9 & 12 & 10 & 10 \\
\hline $\begin{array}{l}\text { MCF7-RAL (GMB) } \\
\text { p74 }\end{array}$ & 11 & 12 & 11 & 11 & 8 & 9 & 11 & 12 & 14 & 15 & 6 & 6 & $x$ & $x$ & 9 & 12 & 10 & 10 \\
\hline ECC1 ATCC & 10 & 11 & 9 & 12 & 9 & 10 & 9 & 9 & 14 & 15 & 9 & 10 & $x$ & $\mathrm{x}$ & 8 & 8 & 11 & 12 \\
\hline
\end{tabular}

Figure 1. Verification of cell line identity by DNA fingerprinting. See Materials and methods.

p42/44 MAPK (Thr202/Tyr204) (E10) antibody (Cell Signalling), p42/44 MAP kinase antibody (Cell Signalling). ß-actin antibody AC-15 (Sigma) was used as a loading control. Appropriate horseradish peroxidase-conjugated secondary antibody was used to visualize bands using an Amersham Western Blotting Detection kit (GE Healthcare).

Histology and immunohistochemistry. Tissues were fixed in $10 \%$ phosphate-buffered formaldehyde for $48 \mathrm{~h}$, subsequently embedded in paraffin, sectioned and stained. Hematoxylin and eosin (H\&E) staining was used to evaluate tumor tissue morphology and extent of necrosis. Immunohistochemistry for Ki-67 (dilution 1:6000) was performed using rabbit polyclonal antibodies from Vector Labs (Burlingame, CA) and Cell Signalling, respectively. Immunostaining was preceded by antigen retrieval in citrate buffer pH6 using a $750 \mathrm{~W}$ microwave oven, boiling the slides at maximum setting for $3 \mathrm{~min}$ and at low setting for another $7 \mathrm{~min}$. A rabbit Vectastain kit (Vector) was used to develop the immunohistochemical reaction using diaminobenzidine as chromogen. Microphotographs were taken using a Nikon Optiphot research microscope with a x10 and x 20 Plan/Apo objectives and a x 10 ocular lens connected to a digital photographic camera (Optronics, Magnafire camera, Optronics, Goleta, CA).

Statistical analysis. The growth rates in Fig. 2A and B were estimated for each individual test by fitting the weight of DNA/well to the linear time term. The rates were compared using Wilcoxon rank-sum tests. The tumor growth data were analyzed using growth curve models, where tumor cross sectional area (CSA) was fit assuming a linear function of time. The intercepts and the slopes were used as random effects at the individual tumor level to allow deviation of individual tumor growth from the mean growth of the group. Random mouse effects were included to account for withinanimal clustering. The estimated curves were plotted and the fit examined. The differences in rates were estimated by the interaction term between time and the treatment. The comparisons of either the DNA weight/well or CSA at each time point were also conducted by using Wilcoxon rank-sum tests. All tests were 2-sided with 0.05 type I error.

\section{Results}

Verification of cell line identity. DNA profiling of the cell lines was conducted using the PowerPlex 1.2 System resulting in the generation of allelic scores for 8 polymorphic STR loci and the amelogenin locus which are presented in Fig. 1A along with the scores for MCF-7 and ECC-1 cells reported in the ATCC STR database. Data from the amelogenin gene amplification were consistent with all samples being of female origin as expected. Allelic score data from the 8 polymorphic STR loci reveal a pattern almost identical among the 5 MCF7 lines that is very closely related to the scores reported for MCF-7 by the ATCC, and consistent with their presumptive identity. Scores for 5 of the 8 loci (D13S317, D7S820, D16S539, TH01 and TPOX) were identical among the study and ATCC MCF-7 cells (Fig. 1A, areas of identity 
A.

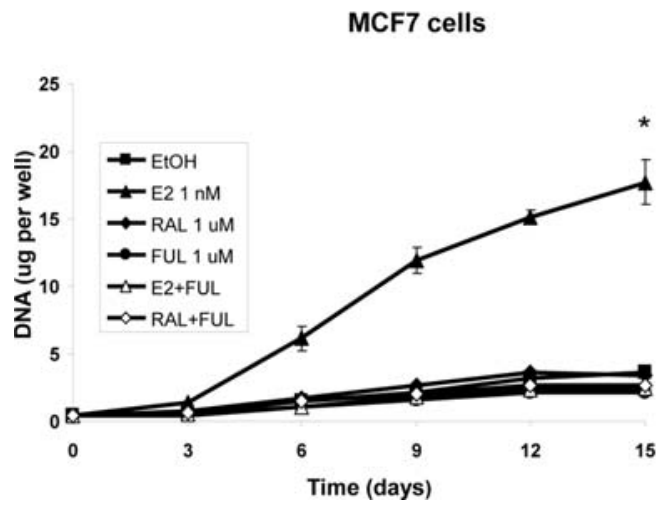

C.

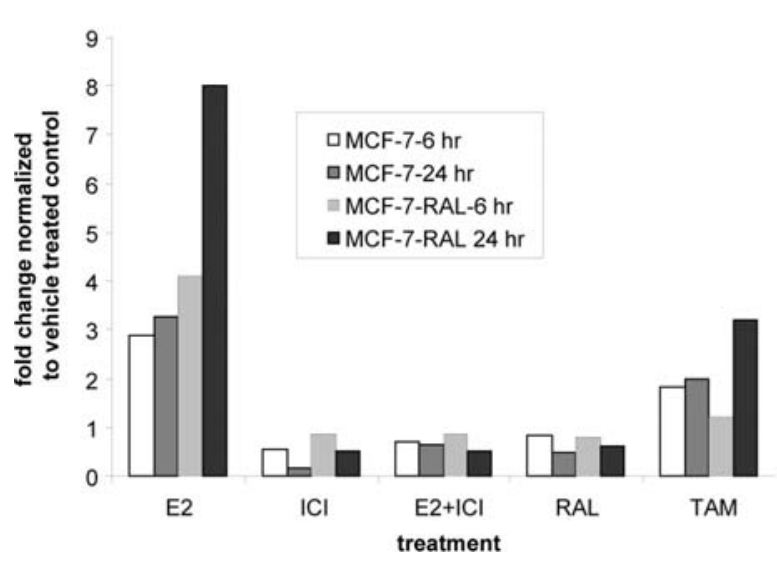

B.

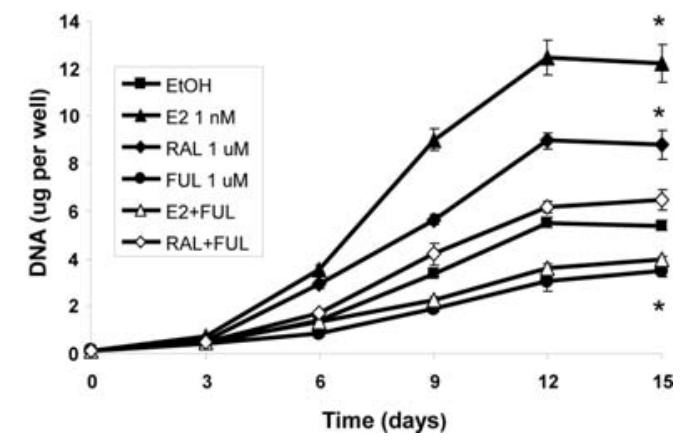

D.

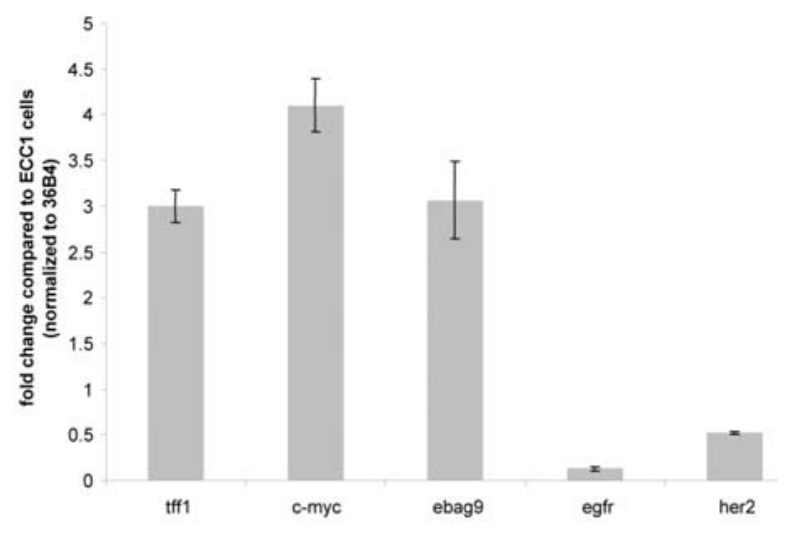

Figure 2. The MCF7-RAL cells are spontaneously growing cells that are stimulated by raloxifene (RAL) and 17ß-estradiol ( $\mathrm{E}_{2}$ ). (A) Three days before seeding the MCF7 cells were cultured in $\mathrm{E}_{2}$-free conditions, RPMI-yellow media with charcoal stripped FBS. The MCF-7 cells were than seeded in a 24-well plate and 24-h post seeding the cells were treated with vehicle, $1 \mathrm{nM} \mathrm{E}, 1 \mu \mathrm{M}$ RAL, $1 \mu \mathrm{M}$ fulvestrant (FUL) and combination of drugs as described in Materials and methods. (B) MCF7-RAL cells were seeded and treated in an identical manner as in (A). (C) MCF-7 and MCF7-RAL cells were either $\mathrm{E}_{2}$ or RAL starved for 3 days before transfection with the appropriate reporters. Twenty-four h post transfection the cells were treated with vehicle control (EtOH), $1 \mathrm{nM} \mathrm{E}_{2}, 1 \mu \mathrm{M}$ RAL, $1 \mu \mathrm{M}$ TAM, $1 \mu \mathrm{M}$ FUL and combination of $1 \mathrm{nM} \mathrm{E}$ and $1 \mu \mathrm{M}$ FUL. Luciferase activity was measured 6 and $24 \mathrm{~h}$ after post treatment. (D) Expression of ER $\alpha$-regulated genes in MCF7-RAL cells in steady state. Error bars = standard error of the mean (SEM); ${ }^{*}$ p $<0.05$, statistically significant finding as compared to EtOH-treated cells.

highlighted in pink), but there was some evidence of genetic drift in some of the study lines. ATCC MCF-7 cells have D5S818 allelic scores of 11 and 12, whereas 4 of the study lines (WS8, 5C, 2A and ICI) only have one allele (12) (allelic loss highlighted in green), whereas the MCF7-RAL cells have two alleles at this locus: 12 and 13 (variant allele highlighted in blue). Similarly, for the vMA locus, the ATCC cells have alleles 14 and 15, as do the 5C, 2A and RAL cells, whereas the WS8 and ICI cells only have one allele; 15. Scores for the CSF1PO locus were identical among the lines showing a single allele (10), with the exception of the $5 \mathrm{C}$ cells that have an additional allele at this locus (11). The minor variations in the DNA profile exhibited by the MCF-7 cells are similar to the sort of genetic drift that has been seen previously among sub-lines of cells cultured independently (41), and overall these fingerprinting data confirm the presumptive identity of the lines as being of MCF-7 origin. Furthermore, the profiles from the study cell lines derived from MCF-7 (WS8) show that they are more closely related to each other than to the ATCC MCF-7 cells, again consistent with their having been derived from a common ancestor subline.
Development of a novel raloxifene-resistant tumor cell line, MCF7-RAL. To examine the effects of long-term raloxifene treatments on breast cancer cell growth we derived a novel breast raloxifene-resistant cell line, MCF7-RAL (GMB). The MCF7-RAL (GMB) cells were developed by continuously passaging cells in estrogen-free media supplemented with $1 \mu \mathrm{M}$ raloxifene for at least 1 year. The fingerprinting data from the independently obtained MCF7 cells p184 and MCF7-RAL p74 (GMB) cells reveal a pattern of allelic scores that is identical to the scores reported for the ATCC MCF-7 cells, and highly divergent from the pattern reported for non-related cells such as the ATCC ECC-1 cells (Fig. 1B). These data suggest that the cell lines used in this study are in fact of ATCCMCF-7 origin and not a variant of the MCF-7WS8 clone. For clarity the MCF-7RAL (GMB) are referred to as MCF-7RAL throughout this paper.

Currently, the MCF7-RAL cells have been propagated in RAL containing medium for approximately 10 years. The growth characteristics in vitro were compared and contrasted with wild-type MCF-7. Within 3 days of treatment the MCF7 cells are significantly $(\mathrm{p}=0.02)$ stimulated by $1 \mathrm{nM} \mathrm{E}, 2$.2-fold increase as compared to vehicle-treated controls (Fig. 2A). 
A.

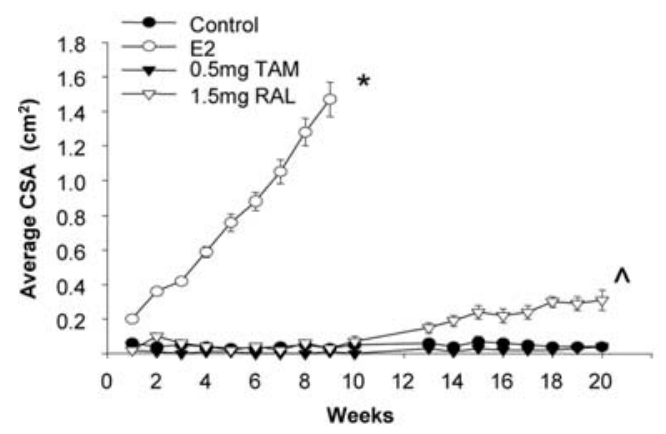

C.

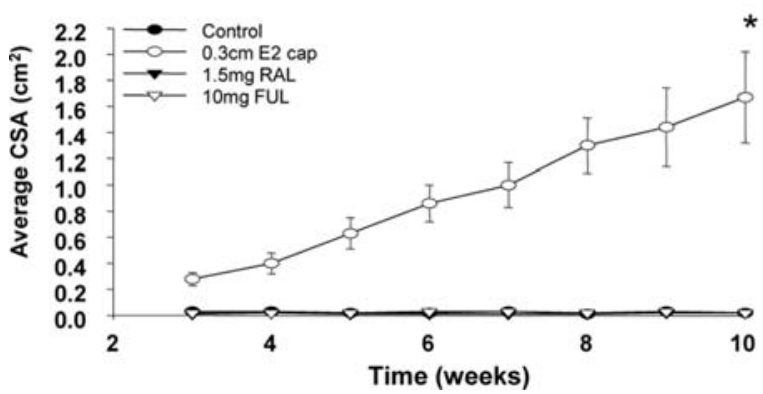

B.

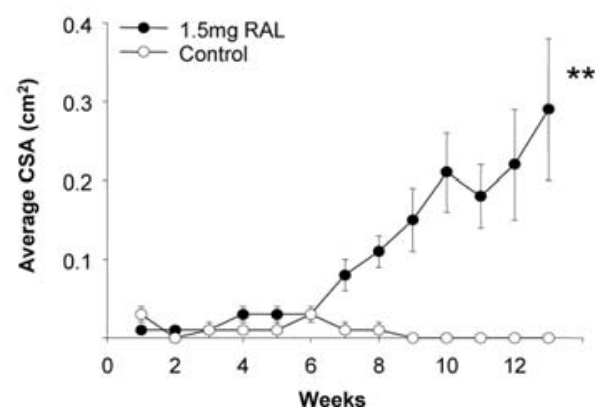

D.

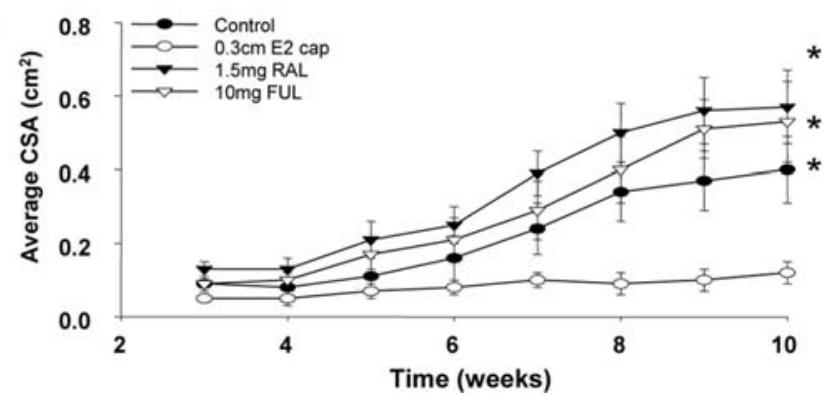

Figure 3. Establishment of MCF7-RAL tumor xenograft model. (A) MCF7-RAL-resistant cells $\left(1 \times 10^{7}\right)$ were injected into the axillary mammary fat pads of ovariectomized athymic mice. The mice were then divided into 4 groups and treated as follows: placebo, implanted with silastic $0.3-\mathrm{cm}_{2} \mathrm{E}_{2}$ capsule, orally gavaged with RAL (1.5 mg daily) and TAM (1.5 mg daily). (B) A single tumor from the RAL-treated group was transplanted (passage 1) into 20 naïve ovariectomized athymic mice and divided into 2 groups: placebo and RAL treated. Error bars $=\mathrm{SEM} ;{ }^{*} \mathrm{p}<0.0001, \mathrm{E}_{2}$ vs. all other treatment groups; ${ }^{\wedge} \mathrm{p}=0.048$ RAL vs. control. ${ }^{* *} \mathrm{p}=0.05$, RAL vs. control (C) MCF7- $\mathrm{E}_{2}$ and MCF7-RAL tumor xenogratfs were bi-transplanted into each ovariectomized athymic mouse (total of 40). The MCF7- $\mathrm{E}_{2}$ tumor was implanted in the left and the MCF7-RAL tumor was implanted in the right axillary mammary fat pad. The mice were randomized into groups of 10 and implanted with $0.3-\mathrm{cm} \mathrm{E}_{2}$ capsule or treated with RAL (1.5 mg daily), FUL (5 mg s.c., twice a week) or no treatment (control). (C) MCF7- $\mathrm{E}_{2}$ tumors; (D) MCF7-RAL tumors; error bars = SEM; ${ }^{\mathrm{p}}<0.05, \mathrm{E}_{2}$ vs. all other treatment groups.

Maximum induction, 4.8-fold increase as compared to control was observed at day 15 . The $\mathrm{E}_{2}$-induced growth of the MCF7 cells was blocked by $1 \mu \mathrm{M}$ FUL treatments. In contrast to $\mathrm{E}_{2}$, $1 \mu \mathrm{M}$ RAL did not stimulate the growth of the MCF7 cells. Similarly to the MCF7 cells, within 3 days of treatments, $\mathrm{E}_{2}$ significantly $(\mathrm{p}=0.02)$ induced the growth of the MCF7-RAL cells (Fig. 2B). Maximum $\mathrm{E}_{2}$ induction was observed at day 9, 2.67-fold increase as compared to control. At day 3 of treatment RAL also significantly $(\mathrm{p}=0.02)$ induced the growth of the MCF7-RAL cells. Maximum RAL induction was observed at day 6, 2.1-fold increase as compared to the controls. The $\mathrm{E}_{2}$ and RAL-induced growth of the MCF7-RAL cells was significantly inhibited by $1 \mu \mathrm{M}$ FUL treatments within 3 $(\mathrm{p}=0.04)$ and 6 days $(\mathrm{p}=0.02)$ of treatment, respectively. In addition, the MCF7-RAL cells were spontaneously growing.

To further characterize the RAL-resistant phenotype of the MCF7-RAL cells we determined the protein expression levels of ER $\alpha$. To determine the protein levels of ER $\alpha$ in MCF7 and MCF7-RAL cells we treated the cells with EtOH, $1 \mu \mathrm{M} \mathrm{RAL}, 1 \mathrm{nM} \mathrm{E}$ and $1 \mu \mathrm{M}$ FUL for $48 \mathrm{~h}$. The ER $\alpha$ protein levels in the MCF7-RAL cells are regulated in an identical manner as in the parental MCF7 cells (data not shown). Treatments with $1 \mathrm{nM} \mathrm{E}_{2}$ and $1 \mu \mathrm{M}$ FUL decreased the protein levels of ER $\alpha$, while treatments with $1 \mu \mathrm{M}$ RAL maintained the protein expression of ER $\alpha$. The levels of total MAPK and total AKT in the MCF7-RAL cells appeared to remain unchanged, regardless of treatment, when compared to the parental, MCF7 cells. However, the levels of phosphorylated MAPK, increased in the EtOH-treated MCF7-RAL cells (data not shown). Luciferase reporter assays indicated that $1 \mathrm{nM} \mathrm{E}_{2}$ treatments significantly induced transcriptional activation of the reporter in MCF7 and MCF7-RAL cells (Fig. 2C) consistent indicating similar activity of ER $\alpha$ in the parental and resistant cell line. Fulvestrant (FUL) and RAL treatments did not induce activation of the reporter. Furthermore, FUL treatments abolished the $\mathrm{E}_{2}$-dependent reporter activity. TAM treatments significantly induced reporter activity in both MCF7 and MCF7-RAL cells at the 24-h time point.

The MCF7-RAL cells grew spontaneously and were inhibited by FUL treatment (Fig. 2B). To further characterize the RAL-resistant phenotype of the MCF7-RAL cells at steady state, we determined by quantitative real-time PCR, the basal mRNA expression of ER $\alpha$-regulated genes in MCF7 and MCF7-RAL cells (Fig. 2D). In the basal state, the MCF7RAL cells exhibited 3-fold up-regulation of tff-1, 4.1-fold upregulation of the c-myc and 3.1-fold up-regulation of ebag9. In contrast, the levels of egfr and her 2 were down-regulated by 7.7 - and 1.99-fold, respectively.

Development of an MCF7-RAL xenograft tumor model. To develop MCF7-RAL xenograft tumor model in vivo, $1 \times 10^{7}$ MCF7-RAL cells were injected into the mammary fat pads of nude athymic mice as described in Materials and methods. The mice were treated with vehicle, implanted with $0.3-\mathrm{cm}$ 

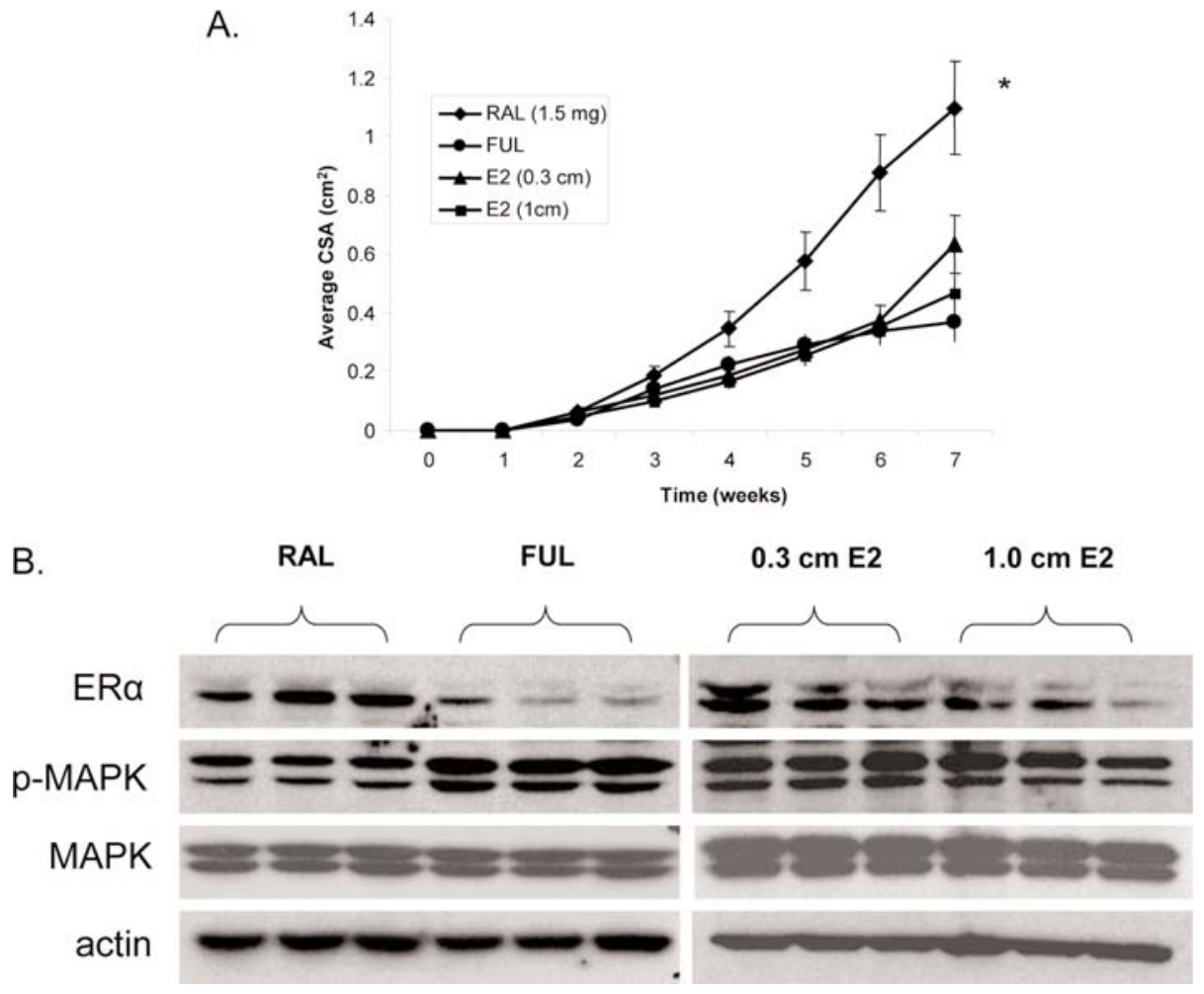

Figure 4. Pre- and post-menopausal concentrations of $\mathrm{E}_{2}$ significantly impair the growth of long-term RAL-treated MCF7-RAL xenografts. (A) MCF7-RAL tumor xenografts serially transplanted for at least 8 years were implanted into 45 ovariectomized athymic mice. The animals were treated with RAL (1.5 mg daily), FUL (5 mg s.c twice weekly) or implanted with either $0.3-\mathrm{cm}$ or $1.0-\mathrm{cm}$ silastic $\mathrm{E}_{2}$ capsules. (B) Western blot analysis of protein extracts collected from (A). * $\mathrm{p}=0.001 \mathrm{RAL}$ vs. all other treatment groups.

silastic $\mathrm{E}_{2}$ capsule or orally gavaged with $1.5 \mathrm{mg}$ daily RAL or $0.5 \mathrm{mg}$ daily TAM. At week 9 , average cross sectional area (CSA) of the estradiol-treated group was $1.47 \mathrm{~cm}^{2}$, significantly greater $(\mathrm{p}<0.0001)$ than the control and the other treatment groups (Fig. 3A). The $\mathrm{E}_{2}$-treated mice grew large tumors and were sacrificed at week 10 because of ethical considerations. By week 15, palpable tumors were observed in the RAL-treated group (average CSA $=0.24 \mathrm{~cm}^{2}$ ) which were significantly larger than the control group $(\mathrm{p}=0.048)$ (Fig. 3A). At week 20, a single tumor from the raloxifenetreated group was excised, resected and transplanted into 20 ovariectomized athymic mice (Fig. 3B). The mice were divided into control (no treatment) and a RAL- (1.5 mg daily) treated group. Starting at week 7, RAL promoted tumor growth which by the conclusion of the experiment at week 13 was statistically significant as compared to the control group ( $\mathrm{p}<0.05)$ (Fig. 3B).

To further characterize the MCF7-RAL tumor xenograft model and to determine the effects of $E_{2}$ and RAL on estrogen and raloxifene-dependent breast tumor growth, we bitransplanted MCF7-E 2 and MCF7-RAL tumors on opposite sides in the axillary mammary fat pads of the same animal. MCF7- $E_{2}$ xenografts were implanted into the left and the MCF7-RAL xenografts were implanted into the right mammary fat pad of 40 ovariectomized athymic mice. As anticipated the $\mathrm{E}_{2}$-treated MCF7- $\mathrm{E}_{2}$ tumors displayed robust tumor growth and at week 10 the mean tumor size was $1.67 \mathrm{~cm}^{2}$ (Fig. 3C). No tumor growth was observed in the control, RAL- and FUL-treated groups (Fig. 3C). In contrast, at week 10, RAL and FUL stimulated MCF7-RAL tumor growth while the $\mathrm{E}_{2}$-treated tumors exhibited minimal growth (Fig. 3D). At week 10, the mean size of the RAL- and FUL-treated tumors was 0.57 and $0.53 \mathrm{~cm}^{2}$, respectively. Interestingly, spontaneous tumor growth was observed in the control MCF7-RAL (at this point considered passage 3 ) (mean tumor size $=0.4 \mathrm{~cm}^{2}$, $\mathrm{p}<0.05$ as compared to the $\mathrm{E}_{2}$ group) (Fig. 3D).

Long-term RAL treatments of the MCF7-RAL tumor xenogratfs. To determine the effects of $\mathrm{E}_{2}$ on long-term RALtreated MCF7-RAL xenografts, we evaluated the effects of pre- and post-menopausal levels of $E_{2}$ (34) on the growth of MCF7-RAL tumors that were serially transplanted and continuously treated with RAL for at least 8 years. The MCF7-RAL tumor xenografts were transplanted into 45 ovariectomized athymic mice that were treated with RAL, FUL and 0.3 - or 1.0-cm silastic $\mathrm{E}_{2}$ capsules (Fig. 4A). At week 7, the RAL-treated xenografts exhibited a statistically significant $(\mathrm{p}<0.001)$ RAL-stimulated growth (mean CSA $=1.1 \mathrm{~cm}^{2}$ ) as compared to the FUL, 0.3 and $1.0 \mathrm{~cm} \mathrm{E}_{2}$-treated tumors (mean CSA $=0.37,0.63,0.46 \mathrm{~cm}^{2}$, respectively). There were no statistical differences between the FUL, 0.3 and $1.0 \mathrm{~cm}$ $E_{2}$-treated tumors. To further characterize the effects of $E_{2}$ on the long-term RAL-treated MCF7-RAL tumor xenografts we analyzed the ER $\alpha$ expression of the xenografts (Fig. 4B). The long-term RAL-treated MCF7-RAL xenografts continue to express ER $\alpha$ and RAL treatments increased the expression of $\mathrm{ER} \alpha$ while FUL treatments down-regulated the expression of ER $\alpha$. No differences in ER $\alpha$ protein expression was observed between the two different concentrations of $E_{2}$ treated tumors. 
A.

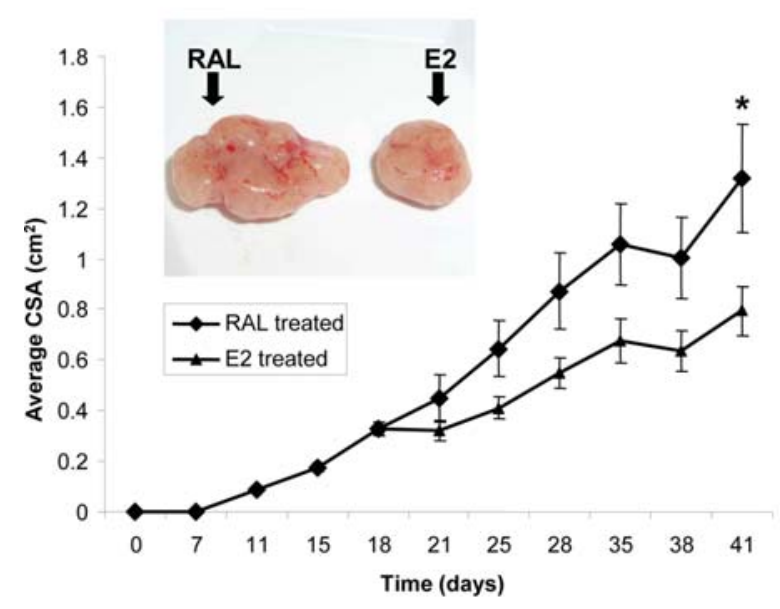

RAL treated E2 treated

B.
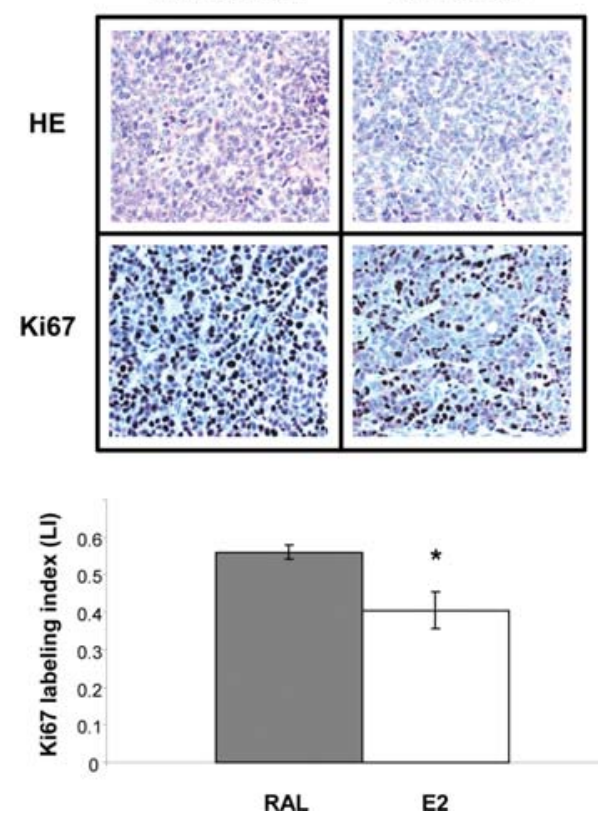

Figure 5. 17ß-estradiol treatments impair the growth of established MCF7-RAL xenografts. (A) Long-term RAL-treated MCF7-RAL xenografts were implanted into 30 ovariectomized athymic mice and the animals were treated with RAL until the cross sectional area (CSA) of the tumors reached $0.3 \mathrm{~cm}^{2}$. The animals were than randomized into 2 groups: continued RAL treatments or implanted with $0.3-\mathrm{cm}_{2}$ capsules. Estradiol treatments significantly impaired the growth of the MCF7-RAL xenografts by day 38 (20 days post-introduction of $\mathrm{E}_{2}$ ). Insert: representative images of $\mathrm{E}_{2}$ - and RAL-treated tumors. (B) Histological analysis of tumors from (A). ${ }^{*} \mathrm{p}=0.02 \mathrm{RAL} v \mathrm{v}$. $\mathrm{E}_{2}$.

Estrogen treatments inhibit the growth of established MCF7$R A L$ tumors. To determine the effects of $\mathrm{E}_{2}$ on established MCF7-RAL tumors, MCF7-RAL tumor xenografts were implanted into ovariectomized athymic nude mice and the animals were treated with RAL until the average CSA of the tumors reached $0.3 \mathrm{~cm}^{2}$. At this point the animals were randomized into 2 groups: 1) continued RAL treatments and 2) implanted with 0.3-cm $E_{2}$ capsules (Fig. 5A). Within 3 days post- $\mathrm{E}_{2}$ implantation, there were visible morphological and size differences between the RAL- and $\mathrm{E}_{2}$-treated tumors (Fig. 5A insert). At day 7, the mean CSA was $0.64 \mathrm{~cm}^{2}$ for the RAL-treated and $0.41 \mathrm{~cm}^{2}$ for the $\mathrm{E}_{2}$-treated tumors. At day 17 the CSA of the RAL-treated tumors was $1.00 \mathrm{~cm}^{2}$ and the CSA of the $\mathrm{E}_{2}$-treated tumors was $0.64 \mathrm{~cm}^{2}(\mathrm{p}=0.03)$. At the end-point of the experiment statistically significant differences $(\mathrm{p}=0.02)$ were observed between the RAL-treated tumors (average CSA $=1.32 \mathrm{~cm}^{2}$ ) and the $\mathrm{E}_{2}$-treated tumors (average CSA $=0.79 \mathrm{~cm}^{2}$ ) (Fig. 5A).

Histological analysis of the RAL- and $\mathrm{E}_{2}$-treated tumors at the conclusion of the experiment (Fig. 5B) by hematoxylin and eosin staining indicated that there are no significant morphological changes between the two treatment groups. However, significant differences in the expression of Ki-67, a known marker of proliferation, were observed between the two groups. There were significant statistical differences $(p=0.02)$ between the average labeling index (LI) of the RAL-treated group and the $\mathrm{E}_{2}$-treated group which were $0.56 \pm 0.04$ and $0.40 \pm 0.09$, respectively.

Effects of long-term estrogen treatments on the growth of MCF7-RAL tumors. To determine the effects of long-term $\mathrm{E}_{2}$ treatments on the growth of MCF7-RAL tumor xenografts we transplanted long-term RAL-treated MCF7-RAL tumors into 45 ovariectomized athymic mice. The mice were divided into 3 groups: no treatment, RAL and $0.3 \mathrm{~cm} \mathrm{E}_{2}$ (Fig. 6A). Three weeks post-implantation the average CSA of the tumors were $0.17,0.08$ and $0.09 \mathrm{~cm}^{2}$ for the RAL, placebo and the $0.3-\mathrm{cm} \mathrm{E}_{2}$-treated tumors. At week 5, differences could be observed between the treatment groups; the average CSA of the RAL-treated tumors was $0.41 \mathrm{~cm}^{2}$ and the average CSA of the $0.3-\mathrm{cm} \mathrm{E}_{2}$-treated tumors was $0.11 \mathrm{~cm}^{2}$. The average CSA of the untreated tumors was $0.2 \mathrm{~cm}^{2}$ indicating spontaneously growing tumors. The $0.3-\mathrm{cm} \mathrm{E}_{2}$ treatment was continued for additional 5 weeks and at week 10 the average CSA was $0.32 \mathrm{~cm}^{2}$. At that point the $\mathrm{E}_{2}$-treated tumors were excised, resected and bitransplanted into 25 ovariectomized athymic mice. The animals were divided into 5 groups: RAL, placebo, $0.3 \mathrm{~cm} \mathrm{E} \mathrm{E}_{2}$, FUL and combination of $\mathrm{E}_{2^{-}}$and RAL-treated (Fig. 6B). Treatment with RAL continued to induce the growth of the MCF7-RAL tumor and at week 8, the average CSA was $1.3 \mathrm{~cm}^{2}$. At week 8 , the average CSA of the placebo and the FUL-treated tumors was 0.36 and $0.29 \mathrm{~cm}^{2}$. Unexpectedly, $E_{2}$ treatments either individually or in combination with RAL induced the growth of the MCF7-RAL xenografts. At week 8 the average CSA of the $\mathrm{E}_{2}$-treated tumors was $0.64 \mathrm{~cm}^{2}$ and combination of $\mathrm{E}_{2}$ and RAL treatments resulted in tumor growth (average CSA $=1.15 \mathrm{~cm}^{2}$ ). The placebo, $\mathrm{E}_{2}$ and FUL treatments were continued and at week 10 the average CSA of the tumors was: $0.49,1.16$ and $0.52 \mathrm{~cm}^{2}$. The growth rates of the RAL-treated tumors were significantly different compared to the placebo ( $\mathrm{p}=0.003)$ and FUL-treated, tumors $(\mathrm{p}=0.005)$. However, the growth rate of the $\mathrm{E}_{2}-$ and $\mathrm{E}_{2}$ + RAL-treated tumors was indistinguishable from the RALtreated tumors. At week 10 the $\mathrm{E}_{2}$-treated tumors were 
A.

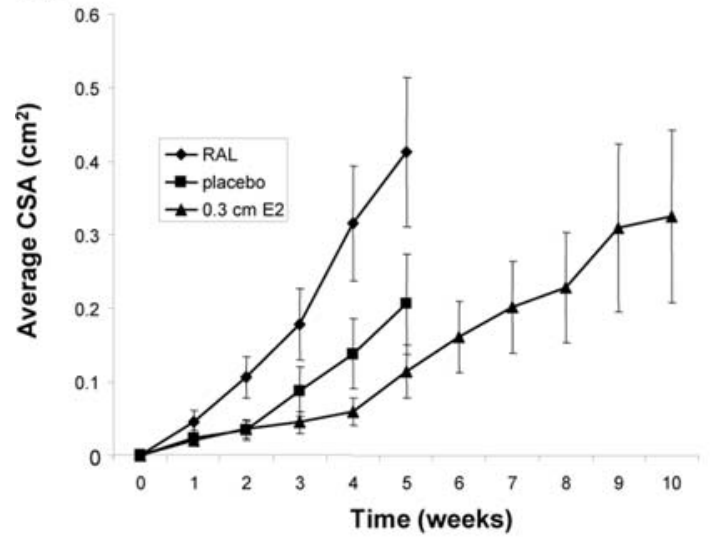

C.

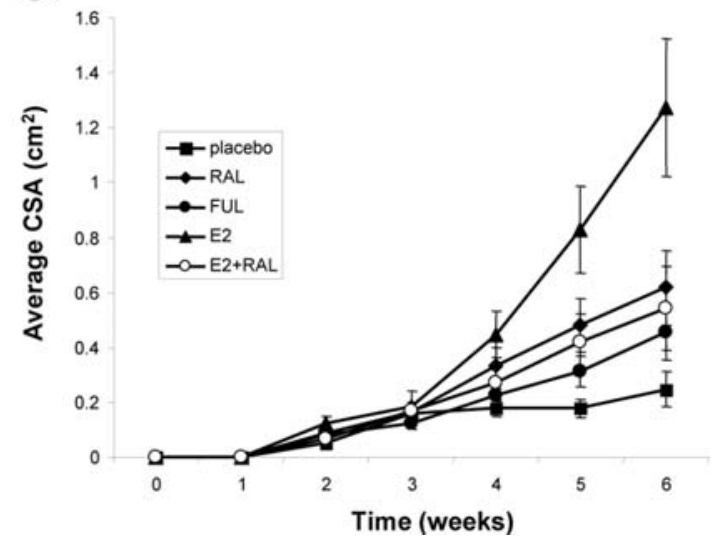

B.

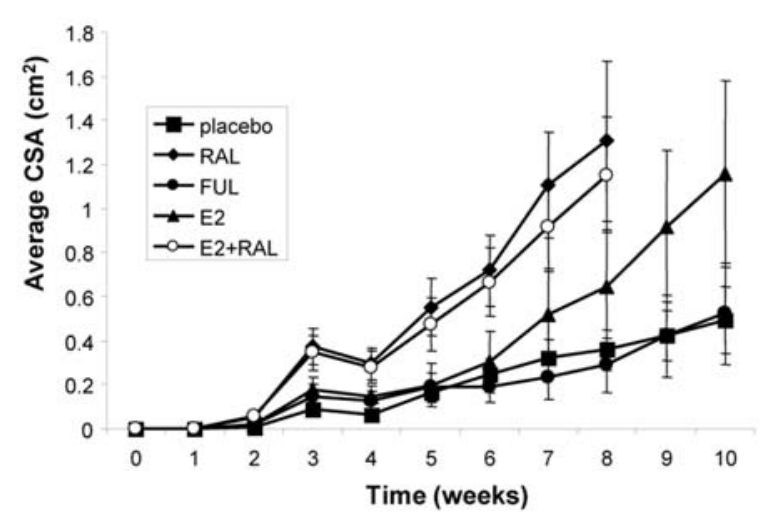

D.

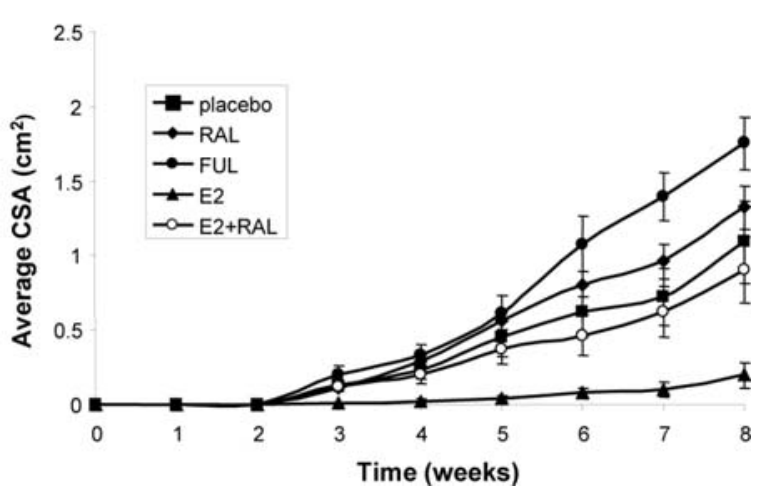

Figure 6. Long-term estrogen and raloxifene treatments result in changes in the phases of SERM resistance. (A) MCF7-RAL tumor xenografts were implanted into 45 ovariectomized athymic mice, the mice were divided into 3 groups and were either left untreated, treated with RAL (1.5 mg/daily) or implanted with 0.3-cm $\mathrm{E}_{2}$ capsules. (B) $\mathrm{E}_{2}$-treated tumors from (A) were resected and re-transplanted into 25 ovariectomized athymic mice that were either left untreated or treated with RAL (1.5 mg/daily), FUL ( $5 \mathrm{mg}$ subcutaneously, twice weekly), implanted with 0.3-cm $\mathrm{E}_{2}$ capsules and combination of RAL and $\mathrm{E}_{2}$. (C) $\mathrm{E}_{2}$-treated tumors from (B) were serially retransplanted into 25 ovariectomized athymic mice that were either left untreated or treated with RAL, FUL, implanted with 0.3-cm $\mathrm{E}_{2}$ capsules and combination of RAL and $\mathrm{E}_{2}$. (D) RAL-treated tumors from (C) were implanted into naïve animals and continuously treated with RAL for 28 weeks before being implanted into 25 naïve animals that were either left untreated or treated with raloxifene, FUL, implanted with 0.3 -cm $\mathrm{E}_{2}$ capsules and combination of RAL and $\mathrm{E}_{2}$. See Results for a precise description of the evolution of raloxifene resistance and statistical significance of the findings in the individual experiments.

excised, resected and implanted into 25 naïve animals. The treatments were identical to the previous experiment and consisted of placebo, RAL, FUL, $\mathrm{E}_{2}$ and combination of $\mathrm{E}_{2}$ and RAL (Fig. 6C). At week 3 post-implantation there were no significant differences in the average CSA between the various treatments, and the average CSA was $0.05,0.08$, $0.08,0.12$ and $0.06 \mathrm{~cm}^{2}$ for the placebo, RAL-, FUL-, $\mathrm{E}_{2}-$ and the $\mathrm{E}_{2}+\mathrm{RAL}$-treated tumors. However, dramatic changes were observed at week 4 as $\mathrm{E}_{2}$ treatments started to induce significant tumor growth (average CSA $=0.44 \mathrm{~cm}^{2}$ ). In contrast RAL inhibited the estrogen-induced tumor growth as the combination of $\mathrm{E}_{2}+$ RAL treatments average CSA was $0.27 \mathrm{~cm}^{2}$. The average CSA of the RAL-treated tumors was $0.33 \mathrm{~cm}^{2}$ and the placebo- and FUL-treated tumors were 0.18 and $0.22 \mathrm{~cm}^{2}$, respectively. At conclusion of the experiment at week 6, the $\mathrm{E}_{2}$-treated tumors reached average CSA of $1.27 \mathrm{~cm}^{2}$. The average CSA of the RAL-treated tumors was $0.62 \mathrm{~cm}^{2}$ and the $\mathrm{E}_{2}+\mathrm{RAL}$ group was $0.54 \mathrm{~cm}^{2}$. The growth rate of the $\mathrm{E}_{2}-$ treated group was significantly different $(\mathrm{p}<0.01)$ from all other groups with the exception of the RAL-treated tumors, but approached significance $(\mathrm{p}=0.06)$. Upon conclusion of the experiment at week 6 the RAL-treated tumors were excised, resected and implanted into ovariectomized athymic animals that were continuously treated with RAL. Following 28 weeks of continuous RAL treatments the long-term treated MCF7-RAL tumor xenografts were implanted into 25 animals that were divided into 5 groups and treated as follows: placebo, RAL, $E_{2}$, FUL and $E_{2}+$ RAL (Fig. 6D). Within 3 weeks of treatments highly statistically significant differences $(p<0.01)$ emerged between the $E_{2}$-treated tumors and all other treatment groups. At week 3 tumor growth was observed in the placebo, FUL, RAL and $E_{2}+$ RAL while negligible tumor growth was observed in the $\mathrm{E}_{2}$-treated group (average $\mathrm{CSA}=0.008 \mathrm{~cm}^{2}$ ). These differences persisted throughout the duration of the experiment and at its conclusion at week 7 , the average CSA of the $\mathrm{E}_{2}$-treated tumors was $0.1 \mathrm{~cm}^{2}$. In contrast, significant tumor growth was observed in all other treatment groups. Paradoxically, maximum tumor growth was observed in the FUL treatment groups (average CSA = $1.4 \mathrm{~cm}^{2}$ ). Significant tumor growth was also observed in the RAL group $\left(\mathrm{CSA}=0.96 \mathrm{~cm}^{2}\right)$ and in the placebo group (CSA 
A

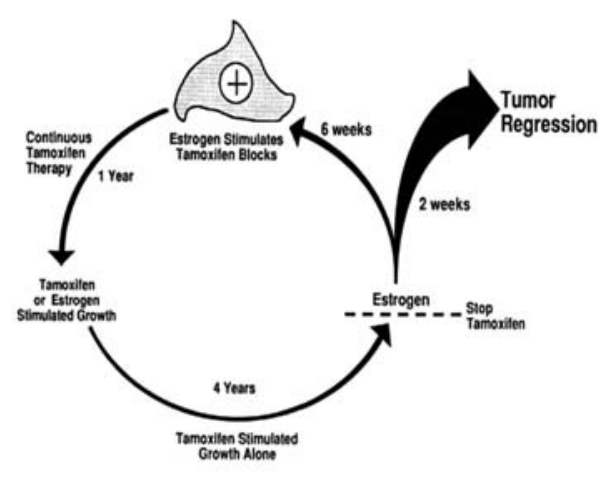

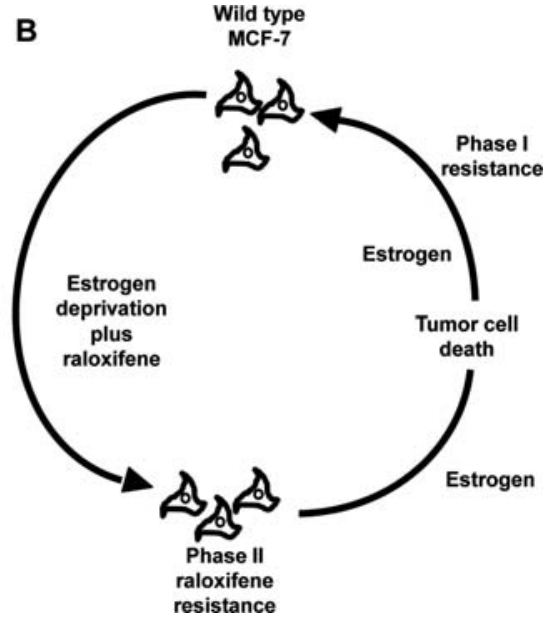

Figure 7. Proposed model of the evolution of acquired raloxifene resistance in ER $\alpha$-positive MCF-7 breast cancer. On the left (Fig. 7A) is our original proposal from cyclical evolution of acquired resistance to tamoxifen in a clonal derivative (MCF-7 WS8) of wild-type MCF-7 cells originally acquired from Dr Dean Edwards (University of Texas, San Antonio, TX) in 1985. All steps in the cycle $(17,18)$ were documented with experimental data in the peer reviewed literature. On the right (Fig. 7B) is a summary of our current results that illustrate the cyclical evolution of acquired resistance to raloxifene in wild-type MCF-7 cells (MCF-7 GMB) acquired from Dr Myles Brown (Dana Farber Cancer Center, Harvard University, Boston, MA) in 1995. The technique of employing an estrogen-deprived environment with raloxifene accelerates the evolution to phase II-acquired resistance where estradiol causes tumor regression. This process can be reversed through phase I-acquired resistance in a continuous estrogenic environment so tumor growth is again controlled by raloxifene treatment. Continuous raloxifene does again cause phase II-acquired resistance and exposes estrogen-induced tumor regression.

$\left.=0.72 \mathrm{~cm}^{2}\right)$. The average CSA of the $\mathrm{E}_{2}+\mathrm{RAL}$ group was $0.62 \mathrm{~cm}^{2}$, indicating that $\mathrm{E}_{2}$ treatments significantly inhibited the RAL-stimulated tumor growth $(\mathrm{p}=0.03)$.

\section{Discussion}

In a previous study, we used a select clone of MCF7 cells (MCF7-WS8) (42) that is extremely sensitive to estrogen stimulation, to create an MCF7 raloxifene-resistant cell line in vitro (MCF7-RAL) (20). In a short-term growth experiment in vivo MCF7-RAL cells grew into tumors in response to raloxifene and tamoxifen but estradiol inhibited tumor growth (20). This biological response to SERMs and estradiol is classified as phase II SERM resistance (1). We have now addressed the question of the predictable creation and evolution of SERM resistance with raloxifene in vivo using a wild-type MCF7 cell line from a source that is external to our laboratory. The origins of the line (MCF7 GMB) were confirmed by genotyping (Fig. 1) and unlike the MCF7-WS8 cells were similar to the wild-type MCF7 from ATCC and the original MCF7 cells derived by Soule (43). We created a new MCF7-RAL cell line that is able not only to grow in response to raloxifene in vitro but eventually grow in response to raloxifene in vivo with phase II resistance, i.e. estradiolinhibited tumor growth (Fig. 3). However, in this 10-year retransplantation study in vivo we demonstrate the reversal of the biological characteristics of phase II anti-hormoneresistant tumor growth with long-term estradiol therapy to phase I resistance; i.e., estradiol- or raloxifene-stimulated growth, and then predominately estradiol-stimulated growth. Raloxifene now acts as an anti-estrogen, inhibiting estradiolstimulated growth (Fig. 6C). Thus raloxifene has the potential to cause the classic evolution of SERM resistance in the clinical setting and reverse the process during long-term physiologic estrogen therapy. Nevertheless clinical studies need to be considered to evaluate the efficacy of estrogen on patients whose breast tumors develop during long-term raloxifene treatment to prevent osteoporosis (16). Current antihormonal therapies used for the treatment of breast cancer (tamoxifen or aromatase inhibitors) can develop acquired resistance in the clinical cells. The best clinical responses to estrogen are observed with high-dose (15 mg) DES therapy following exhaustive anti-hormonal therapy (27). Indeed, one patient had a complete response during the 5-year to DES therapy administered continuously and a further 5-year disease-free response following the cessation of therapy (44). In contrast, no complete responses were observed in the study of Ellis et al (28) probably because the patient population was not selected based on exhaustive anti-hormonal therapy but only failure of therapy following aromatase inhibitors. Experience in the laboratory demonstrates that long-term ( $>5$ years) tamoxifen treatment is necessary to cause the evolution of tamoxifen resistance in vivo to expose the apoptotic actions of physiologic estrogen (18). Consistent with these observations, a profound antitumor effect was noted with physiologic estrogen after 10 years of alternating treatments with raloxifene and physiologic estrogen (Fig. 6D).

With regard to treatment strategies for SERM-resistant disease, it is important to note that the response to the injectable steroidal pure anti-estrogen fulvestrant is unpredictable (Fig. 6). At some stages of acquired resistance, fulvestrant acts as an antitumor agent but at other stimulates tumor growth (Fig. 6). This may in part explain the low reported efficacy of fulvestrant in clinical trials treating patients who already have acquired resistance to tamoxifen or aromatase inhibitors. However, it also appears that the recommended monthly doses of fulvestrant used clinically may be suboptimal and in fact actually enhance tumor growth in tumors with phase II resistance with physiologic estrogen present (45). A recent clinical study on metastatic breast cancer demonstrates that doubling the monthly dose of fulvestrant enhances antitumor activity (46). In a laboratory study, an antitumor dose of fulvestrant in athymic animals implanted 
with phase II-resistant tumors reversed the apoptotic actions of estrogen (45). In the present study, despite using repeated subcutaneous injections of fulvestrant weekly, tumor growth was enhanced in some tumor passages with long-term acquired resistance to raloxifene (Fig. 6D). It appears that the efficacy of fulvestrant may depend both upon bioavailability, pharmacokinetics and, as yet, unresolved pharmacodynamic factors of the steroidal antiestrogens at unknown targets within the tumor with acquired raloxifene resistance.

Two further conclusions emerged from the present study. The variant of MCF7 cells that is closely related to wild-type MCF-7 from ATCC could develop acquired resistance to raloxifene in vitro and the resulting cell line MCF7-RAL grew in response to either estradiol or raloxifene (Fig. 2). MCF7-RAL cells exhibited gene activation consistent with autonomous growth (Fig. 2C). The cells responded to estradiol both in vitro and in vivo as a growth stimulus but only developed raloxifene-stimulated tumors in vivo after 5 months of continuous treatment. This was confirmed by retransplantation into raloxifene-treated ovariectomized athymic mice (Fig. 3B). In contrast to MCF7-RAL cells in vitro, estradiol is no longer a growth stimulus in vivo and completely inhibits tumor development (Fig. 3D). This new biology of estrogen action classifies the MCF7-RAL cells as phase II-resistant in vivo. Secondly, the observation that treatment with tamoxifen in vivo (Fig. 3A) did not result in tumor growth and that this MCF7 variant could not be used to develop acquired tamoxifen resistance in vitro $(\mathrm{H}$. Liu, unpublished), was unusual and unanticipated based on previous studies over two decades. All cells died during incubation with 4-hydroxy-tamoxifen. This observation is currently under investigation as it may provide insight into the cytocidal actions of tamoxifen.

Based on this long-term study, and studies using prostate cancer cells, a general principle is emerging in cancer endocrinology. An androgen-independent cell line, LNCaP 104 $\mathrm{R} 2$ was derived from the androgen-dependent cell line, LNCaP 104 S (47). The LNCaP 104 R2 cells are androgenindependent, continue to express the androgen receptor (AR) and low concentrations of androgen in the media inhibited their growth. Implantation of the LNCap104-R2 cells in male athymic-castrated nude mice resulted in tumor growth, that was inhibited by implantation of testosterone capsules (48). In a subsequent study utilizing the LNCaP 104-R2 tumor model, Chuu et al (49) significantly impaired established tumor growth with androgen treatments; approximately 2 months post-cell injections. However, within 40 days of initiation of androgen treatments tumor growth resumed, which was a clear indication that the tumors adapted to the presence of the androgen and utilized it for growth. Subsequent androgen withdrawal inhibited tumor growth. These data are consistent with the assumption that androgendependent and androgen-independent tumor cells coexist in prostate cancer patients resulting in positive selection of androgen-independent tumor cells during androgen ablation therapies, resulting in androgen-independent growth. Therefore, intermittent androgen replacement therapy has been tested in recent years (50).

Nearly 20 years ago, we first described the antitumor potential of physiologic estrogen to destroy what is now known as phase II-acquired tamoxifen resistance (17) We noted that the interplay of apoptotic estrogen and tamoxifen would create a cyclical method for controlling the growth of ER-postitive breast cancer by purging with estrogen at the appropriate time and then continuing anti-hormone therapy (17). The cycles could be repeated. This original work is summarized in Fig. 7. Our current 10-year in vitro and in vivo study of the evolution of acquired raloxifene resistance was initiated to explore the potential of raloxifene to exhibit acquired resistance in breast cancer during the long-term treatment and prevention of osteoprosis (16). We conclude that the predictable evolution of acquired resistance to the SERM tamoxifen and estrogen deprivation (aromatase inhibitors) also occurs with raloxifene. The current conclusions are summarized in Fig. 7, following the creation of MCF7RAL cells in vitro is a raloxifene/estrogen-free environment which was then transplanted into athymic mice. The development of phase II-acquired resistance i.e.: estrogen-induced apoptosis or estrogen-inhibited tumor growth (51) occurs with raloxifene and the principle is also true for the evolution of acquired androgen withdrawal in prostate cancer in the laboratory (47-49). Preliminary studies to translate these laboratory findings to aid patients have shown merit (27, $28,44)$. Further understanding of the mechanism of sex steroidinduced apoptosis (52) and the definition of vulnerable tumors following exhaustive anti-hormonal therapy have the potential to identify appropriate patient populations to amplify the effectiveness of a sex steroid apoptotic trigger in metastatic breast cancer and possibly prostate cancer (53).

\section{Acknowledgements}

These studies were supported by the following grants: the Department of Defense Breast Program under award number BC050277 Center of Excellence, SPORE in Breast Cancer CA89018 (VCJ), Genuardi's Fund (VCJ), FCCC Core Grant NIH P30 CA006927, the Lynn Sage Breast Cancer Research Foundation (VCJ), the Weg Fund of Fox Chase Cancer Center (VCJ), and the Cancer Center Support Grant (CCSG) Core Grant NIH P30 CA051008. The views and opinions of the author(s) do not reflect those of the US Army or the Department of Defense.

\section{References}

1. Jordan VC: Selective estrogen receptor modulation: Concept and consequences in cancer. Cancer Cell 5: 207-213, 2004.

2. Tamoxifen for early breast cancer: An overview of the randomised trials. Early breast cancer trialists' collaborative group. Lancet 351: 1451-1467, 1998.

3. Jordan VC: Chemoprevention of breast cancer with selective oestrogen-receptor modulators. Nat Rev Cancer 7: 46-53, 2007.

4. Fisher B, Costantino JP, Wickerham DL, et al: Tamoxifen for prevention of breast cancer: Report of the National Surgical Adjuvant Breast and Bowel project P-1 study. J Natl Cancer Inst 90: 1371-1388, 1998.

5. Gottardis MM and Jordan VC: Development of tamoxifenstimulated growth of MCF-7 tumors in athymic mice after longterm antiestrogen administration. Cancer Res 48: 5183-5187, 1988.

6. Gottardis MM, Wagner RJ, Borden EC and Jordan VC: Differential ability of antiestrogens to stimulate breast cancer cell (MCF-7) growth in vivo and in vitro. Cancer Res 49: 4765-4769, 1989.

7. Black LJ, Jones CD and Falcone JF: Antagonism of estrogen action with a new benzothiophene derived antiestrogen. Life Sci 32: 1031-1036, 1983. 
8. Clemens JA, Bennett DR, Black LJ and Jones CD: Effects of a new antiestrogen, keoxifene (ly156758), on growth of carcinogen-induced mammary tumors and on $1 \mathrm{H}$ and prolactin levels. Life Sci 32: 2869-2875, 1983.

9. Gottardis MM and Jordan VC: Antitumor actions of keoxifene and tamoxifen in the $\mathrm{N}$-nitrosomethylurea induced rat mammary carcinoma model. Cancer Res 47: 4020-4024, 1987.

10. Jordan VC, Phelps E and Lindgren JU: Effects of anti-estrogens on bone in castrated and intact female rats. Breast Cancer Res Treat 10: 31-35, 1987

11. Jordan VC: Chemosuppression of breast cancer with tamoxifen: Laboratory evidence and future clinical investigations. Cancer Invest 6: 589-595, 1988

12. Ettinger B, Black DM, Mitlak BH, et al: Reduction of vertebral fracture risk in postmenopausal women with osteoporosis treated with raloxifene: Results from a 3-year randomized clinical trial. Multiple outcomes of raloxifene evaluation (more) investigators. JAMA 282: 637-645, 1999.

13. Cummings SR, Eckert S, Krueger KA, et al: The effect of raloxifene on risk of breast cancer in postmenopausal women: Results from the more randomized trial. Multiple outcomes of raloxifene evaluation. JAMA 281: 2189-2197, 1999.

14. Vogel VG, Costantino JP, Wickerham DL, et al: Effects of tamoxifen vs raloxifene on the risk of developing invasive breast cancer and other disease outcomes: The NSABP study of tamoxifen and raloxifene (STAR) P-2 trial. JAMA 295: 2727-2741, 2006.

15. Barrett-Connor E, Mosca L, Collins P, et al: Effects of raloxifene on cardiovascular events and breast cancer in postmenopausal women. N Engl J Med 355: 125-137, 2006.

16. Martino S, Cauley JA, Barrett-Connor E, et al: Continuing outcomes relevant to evista: Breast cancer incidence in postmenopausal osteoporotic women in a randomized trial of raloxifene. J Natl Cancer Inst 96: 1751-1761, 2004.

17. Wolf DM and Jordan VC: A laboratory model to explain the survival advantage observed in patients taking adjuvant tamoxifen therapy. Recent Results Cancer Res 127: 23-33, 1993.

18. Yao K, Lee ES, Bentrem DJ, et al: Antitumor action of physiological estradiol on tamoxifen-stimulated breast tumors grown in athymic mice. Clin Cancer Res 6: 2028-2036, 2000.

19. O'Regan RM, Osipo C, Ariazi E, et al: Development and therapeutic options for the treatment of raloxifene-stimulated breast cancer in athymic mice. Clin Cancer Res 12: 2255-2263, 2006

20. Liu H, Lee ES, Gajdos C, et al: Apoptotic action of 17betaestradiol in raloxifene-resistant MCF-7 cells in vitro and in vivo. J Natl Cancer Inst 95: 1586-1597, 2003.

21. Song RX, Mor G, Naftolin F, et al: Effect of long-term estrogen deprivation on apoptotic responses of breast cancer cells to 17beta-estradiol. J Natl Cancer Inst 93: 1714-1723, 2001.

22. Song RX, Zhang Z, Mor G and Santen RJ: Down-regulation of BCL-2 enhances estrogen apoptotic action in long-term estradioldepleted ER(+) breast cancer cells. Apoptosis 10: 667-678, 2005.

23. Lewis JS, Meeke K, Osipo C, et al: Intrinsic mechanism of estradiol-induced apoptosis in breast cancer cells resistant to estrogen deprivation. J Natl Cancer Inst 97: 1746-1759, 2005.

24. Lewis JS, Osipo C, Meeke K and Jordan VC: Estrogen-induced apoptosis in a breast cancer model resistant to long-term estrogen withdrawal. J Steroid Biochem Mol Biol 94: 131-141, 2005.

25. Kennedy BJ: Diethylstilbestrol versus testosterone propionate therapy in advanced breast cancer. Surg Gynecol Obstet 120: $1246-1250,1965$.

26. Haddow A, Watkinson JM, Paterson E and Koller PC: Influence of synthetic oestrogens on advanced malignant disease. Br Med J 2: 393-398, 1944

27. Lonning PE, Taylor PD, Anker G, et al: High-dose estrogen treatment in postmenopausal breast cancer patients heavily exposed to endocrine therapy. Breast Cancer Res Treat 67: 111-116, 2001

28. Ellis MJ, Gao F, Dehdashti F, et al: Lower-dose vs high-dose oral estradiol therapy of hormone receptor-positive, aromatase inhibitor-resistant advanced breast cancer: A phase 2 randomized study. JAMA 302: 774-780, 2009

29. Lins AM, Micka KA, Sprecher CJ, et al: Development and population study of an eight-locus short tandem repeat (STR) multiplex system. J Forensic Sci 43: 1168-1180, 1998.

30. Jamerson MH, Johnson MD, Korsmeyer SJ, Furth PA and Dickson RB: Bax regulates c-myc-induced mammary tumour apoptosis but not proliferation in MMTV-c-myc transgenic mice. Br J Cancer 91: 1372-1379, 2004.

31. Labarca $\mathrm{C}$ and Paigen K: A simple, rapid, and sensitive DNA assay procedure. Anal Biochem 102: 344-352, 1980.
32. Dardes RC, Schafer JM, Pearce ST, Osipo C, Chen B and Jordan VC: Regulation of estrogen target genes and growth by selective estrogen-receptor modulators in endometrial cancer cells. Gynecol Oncol 85: 498-506, 2002.

33. Robinson SP and Jordan VC: Antiestrogenic action of toremifene on hormone-dependent, -independent, and heterogeneous breast tumor growth in the athymic mouse. Cancer Res 49: 1758-1762, 1989.

34. O'Regan RM, Cisneros A, England GM, et al: Effects of the antiestrogens tamoxifen, toremifene, and ICI 182,780 on endometrial cancer growth. J Natl Cancer Inst 90: 1552-1558, 1998.

35. Ariazi EA, Lewis-Wambi JS, Gill SD, et al: Emerging principles for the development of resistance to antihormonal therapy: Implications for the clinical utility of fulvestrant. J Steroid Biochem Mol Biol 102: 128-138, 2006.

36. Ariazi EA, Kraus RJ, Farrell ML, Jordan VC and Mertz JE: Estrogen-related receptor alpha1 transcriptional activities are regulated in part via the erbb2/her2 signaling pathway. Mol Cancer Res 5: 71-85, 2007.

37. Rae JM, Johnson MD, Scheys JO, Cordero KE, Larios JM and Lippman ME: Greb 1 is a critical regulator of hormone dependent breast cancer growth. Breast Cancer Res Treat 92: 141-149, 2005.

38. Livak KJ and Schmittgen TD: Analysis of relative gene expression data using real-time quantitative PCR and the 2(delta)(delta)ct method. Methods 25: 402-408, 2001.

39. Ariazi EA, Clark GM and Mertz JE: Estrogen-related receptor alpha and estrogen-related receptor gamma associate with unfavorable and favorable biomarkers, respectively, in human breast cancer. Cancer Res 62: 6510-6518, 2002.

40. Pink JJ and Jordan VC: Models of estrogen receptor regulation by estrogens and antiestrogens in breast cancer cell lines. Cancer Res 56: 2321-2330, 1996.

41. Rae JM, Creighton CJ, Meck JM, Haddad BR and Johnson MD: MDA-MB-435 cells are derived from M14 melanoma cells loss for breast cancer, but a boon for melanoma research. Breast Cancer Res Treat 104: 13-19, 2007.

42. Jiang SY, Langan-Fahey SM, Stella AL, McCague R and Jordan VC: Point mutation of estrogen receptor (ER) in the ligandbinding domain changes the pharmacology of anti-estrogens in ERnegative breast cancer cells stably expressing complementary DNAs for ER. Mol Endocrinol 6: 2167-2174, 1992.

43. Brooks SC, Locke ER and Soule HD: Estrogen receptor in a human cell line (MCF-7) from breast carcinoma. J Biol Chem 248: 6251-6253, 1973.

44. Lonning PE: Additive endocrine therapy for advanced breast cancer - back to the future. Acta Oncol 48: 1092-1101, 2009.

45. Osipo C, Gajdos C, Liu H, Chen B and Jordan VC: Paradoxical action of fulvestrant in estradiol-induced regression of tamoxifenstimulated breast cancer. J Natl Cancer Inst 95: 1597-1608, 2003.

46. Robertson JF, Llombart-Cussac A, Rolski J, et al: Activity of fulvestrant $500 \mathrm{mg}$ versus anastrozole $1 \mathrm{mg}$ as first-line treatment for advanced breast cancer: Results from the first study. J Clin Oncol 27: 4530-4535, 2009.

47. Kokontis J, Takakura K, Hay N and Liao S: Increased androgen receptor activity and altered c-myc expression in prostate cancer cells after long-term androgen deprivation. Cancer Res 54: 1566-1573, 1994.

48. Umekita Y, Hiipakka RA, Kokontis JM and Liao S: Human prostate tumor growth in athymic mice: Inhibition by androgens and stimulation by finasteride. Proc Natl Acad Sci USA 93: 11802-11807, 1996.

49. Chuu CP, Hiipakka RA, Fukuchi J, Kokontis JM and Liao S: Androgen causes growth suppression and reversion of androgenindependent prostate cancer xenografts to an androgen-stimulated phenotype in athymic mice. Cancer Res 65: 2082-2084, 2005.

50. Abrahamsson PA: Potential benefits of intermittent androgen suppression therapy in the treatment of prostate cancer: A systematic review of the literature. Eur Urol (In press).

51. Jordan VC: The 38th David A. Karnofsky lecture: The paradoxical actions of estrogen in breast cancer - survival or death? J Clin Oncol 26: 3073-3082, 2008.

52. Maximov PY, Lewis-Wambi JS and Jordan VC: The paradox of oestradiol-induced breast cancer cell growth and apoptosis. Curr Signal Transduct Ther 4: 88-102, 2009.

53. Jordan VC: A century of deciphering the control mechanisms of sex steroid action in breast and prostate cancer: The origins of targeted therapy and chemoprevention. Cancer Res 69: 1243-1254, 2009. 